\title{
Reklama suplementów diety - analiza prawna
}

\section{Advertisement of Diet Supplement - Legal Analysis}

\begin{abstract}
Synopsis. Celem niniejszego artykułu jest analiza prawna reklamy suplementów diety i problemów jakie napotykają konsumenci oraz przedsiębiorcy $\mathrm{Z}$ uwagi na brak kompleksowego uregulowania przedmiotowych produktów. Nacisk został położony na przeanalizowanie aktów prawnych ustanowionych na poziomie Unii Europejskiej oraz aktów obowiązujących w prawie krajowym, a także przykładach zastosowania powyższych regulacji w orzecznictwie sądów oraz decyzji kompetentnych organów. W obliczu częstych problemów z zastosowaniem się do przepisów właściwych suplementom diety, analiza taka okazuje się niezbędna dla porównania różnych reżimów prawnych rządzących reklamą suplementów diety oraz kompleksowego uregulowania dotyczącego produktów leczniczych.
\end{abstract}

Słowa kluczowe: suplement diety, żywność, reklama, produkt leczniczy

\begin{abstract}
The purpose of this article is a legal analysis of advertising for dietary supplements and problems encountered by consumers and entrepreneurs due to the lack of comprehensive regulation of the products. Emphasis was placed on analyzing legal acts established at the level of the European Union and acts in force in national law, as well as examples of the application of the above regulations in court decisions and decisions of competent authorities. Given the frequent problems with adherence to provisions applicable to dietary supplements, such an analysis turns out to be necessary to compare the various legal regimes governing the advertising of dietary supplements and comprehensive regulation of medicinal products.
\end{abstract}

Key words: diet supplement, food, advertisement, medical product

JEL Classification: K390

\section{Wprowadzenie}

Unia Europejska na poziomie wspólnotowym szczegółowo uregulowała zasady reklamy produktów uważanych za wymagające szczególnego i ostrożnego traktowania ze względu na swoje właściwości. Są nimi przede wszystkim produkty sensytywne, takie jak produkty lecznicze. Suplementy diety zaklasyfikowano zaś jako żywność, a dokładnie środek spożywczy. Przepisy regulujące ich reklamę nie są tak restrykcyjne i szczegółowe jak te dotyczące produktów leczniczych.

Polski prawodawca nie zdecydował się na stworzenie ustawy kompleksowo traktującej o suplementach diety, tak jak stało się to w przypadku produktów leczniczych. Wynika to ze stosunkowo niedługiej obecności takich produktów na rynku oraz trudnościach w ich

\footnotetext{
${ }^{1}$ mgr, Wydział Prawa i Administracji Uniwersytetu Warszawskiego, ul. Krakowskie Przedmieście 26/28, 00-927 Warszawa, e-mail: ksiazczak.karolina@o2.pl

${ }^{2}$ mgr, Wydział Prawa i Administracji Uniwersytetu Warszawskiego, ul. Krakowskie Przedmieście 26/28, 00-927 Warszawa, e-mail: bartek.niescior@gmail.com
} 
klasyfikowaniu. Reklama produktów leczniczych jak i suplementów diety oparta jest na systemie zakazów. W przypadku zakazu bezwzględnego, reklama konkretnego produktu nie jest w ogóle możliwa. Gdy nakaz jest względny, oznacza to, iż niemożliwe jest reklamowanie danego produktu przy wykorzystaniu konkretnych metod lub środków przekazu reklamy (Namysłowska, 2012). Analiza decyzji organów Inspekcji Sanitarnej na wszystkich jej szczeblach oraz wyroków wojewódzkich sądów administracyjnych pozwala stwierdzić, że najczęstszym problemem dotyczącym suplementów diety w reklamie, jest ich oznaczenie niezgodne $\mathrm{z}$ obowiązującymi aktami prawnymi dotyczącymi prawa żywnościowego. Producenci tych środków spożywczych oraz zatrudniani przez nich specjaliści z zakresu reklamy, mimo wystarczająco precyzyjnych reguł dotyczących oświadczeń zdrowotnych i żywieniowych, nie potrafią uchwycić zgodnej z wymaganiami prawnymi granicy pomiędzy reklamą suplementu diety a produktu leczniczego. Praktyka pokazuje również, iż liczą na bezczynność organu konkurencji.

Celem pracy, z uwagi na brak kompleksowego ustawodawstwa traktującego o reklamie suplementów diety, jest przedstawienie i przeanalizowanie aktów prawnych dotyczących reklamy suplementów diety czyli żywności oraz opis podstawowych definicji i funkcji reklamy ww. produktów. Kluczowe jest również ukazanie funkcjonowania i wykładni powyższych zapisów w praktyce orzeczniczej i kompetentnych organów. Na polskim rynku brakuje literatury przedmiotu, która w sposób kompletny opisywałaby prawne aspekty reklamy suplementów diety i problemów pojawiających się podczas klasyfikacji takich produktów. W związku z rosnącą świadomością konsumentów na temat zdrowego stylu życia i wpływu żywienia na zdrowie, istotne staje się stworzenie przez prawodawce, zarówno unijnego jak i krajowego, wyczerpującego uregulowania w tym zakresie.

\section{Akty prawne regulujące reklamę suplementów diety}

Ustawa o bezpieczeństwie żywności i żywienia (u.b.ż.ż) (Dz. U. z 2017 r. poz. 149) jest podstawowym aktem prawnym regulującym reklamę suplementów diety w Polsce. O reklamie tej traktuje jednak w sposób ograniczony. W art. 27 ust. 5 u.b.ż.ż. zapisano, że oznakowanie, prezentacja i reklama suplementów diety nie mogą zawierać informacji stwierdzających lub sugerujących, że zbilansowana i zróżnicowana dieta nie może dostarczyć wystarczających dla organizmu ilości składników odżywczych. Wcześniej zagadnienie to w sposób wyczerpujący regulował art. 46 u.b.ż.ż., został on jednak uchylony w 2015 r. Mimo posługiwania się słowem „reklama”, ustawa powyższa nie zawiera takiej definicji. $\mathrm{Na}$ poziomie UE aktami prawnymi regulującymi reklamę suplementów diety są dyrektywa 2002/46/WE w sprawie zbliżenia ustawodawstw Państw Członkowskich odnoszących się do suplementów żywnościowych (Dz. U. UE. L. z 2002 r. Nr 183) oraz rozporządzenie 1924/2006/WE w sprawie oświadczeń żywieniowych i zdrowotnych dotyczących żywności (Dz. U. UE. L. z 2006 r. Nr 404, str. 9-25). W powyższych aktach prawnych również nie zawarto definicji reklamy suplementów diety, dlatego przy wykładni przepisów jej dotyczących kluczowe okazuje się orzecznictwo sądów krajowych oraz Trybunału Sprawiedliwości Unii Europejskiej (TSUE) jak również bogaty dorobek doktryny.

Posiłkując się definicjami zawartymi $\mathrm{w}$ innych aktach prawnych, orzecznictwie czy słownikach, szczególną uwagę należy zwrócić na definicję reklamy produktu leczniczego, umieszczoną w ustawie Prawo farmaceutyczne (Dz. U. z 2016 r. poz. 2142). Ustawodawca stwierdza w niej, że ,reklamą produktu leczniczego jest działalność polegająca na 
informowaniu lub zachęcaniu do stosowania produktu leczniczego, mająca na celu zwiększenie: liczby przepisywanych recept, dostarczania, sprzedaży lub konsumpcji produktów leczniczych" (art. 52.1). W przypadku spełnienia warunków odpowiadających produktowi leczniczemu, suplement diety podlegać będzie reżimowi właściwemu prawu farmaceutycznemu, czyli restrykcyjnej ustawie Prawo farmaceutyczne. Ze względu na swoją specyfikę i podobieństwo do produktów leczniczych, w stosunku do suplementów diety kluczowe jest wykorzystanie regulacji dotyczących reklamy wprowadzającej w błąd oraz regulacje prawa farmaceutycznego, kiedy to przedmiotowym produktom przypisać można cechy właściwe produktom leczniczym. Znajdują one zastosowanie wtedy, kiedy suplement diety powinien być kwalifikowany jako lek, zarówno ze względu na jego prezentację, jak i funkcję. Regulacje dotyczące produktów leczniczych i suplementów diety łączy podobny cel, czyli ochrona zdrowia i życia publicznego.

W związku z tym, iż obecny stan prawny nie zapewnia regulacji dedykowanych reklamie suplementów diety, konieczne jest skupienie się na aktach prawnych dotyczących prawa konsumenckiego i ogólnego prawa reklamy. W prawie krajowym kluczowa dla tego zagadnienia będzie triada ustaw, tj. ustawa z dnia 16 lutego 2007 r. o ochronie konkurencji i konsumenta (u.z.n.k.) (Dz. U. z 2007 Nr 50, poz. 331), ustawa z dnia 16 kwietnia 1993 r. o zwalczaniu nieuczciwej konkurencji (z.n.k.) (Dz. U. z $1993 \mathrm{Nr}$ 47, poz. 211) oraz ustawa z dnia 23 sierpnia 2007 r. o przeciwdziałaniu nieuczciwym praktykom rynkowym (Dz. U. z 2007 Nr 171, poz. 1206). W sprawach dotyczących reklamy suplementów diety kluczowe są zapisy traktujące o czynach nieuczciwej konkurencji w zakresie reklamy, oparte na art. 16 ust. 1 pkt 2 wyżej wskazanej ustawy.

$\mathrm{Na}$ poziomie wspólnotowym dyrektywy, których zapisy zgodnie $\mathrm{z}$ zasadą pierwszeństwa prawa UE zostały transponowane do wcześniej wymienionych ustaw prawa polskiego będą: 2006/114/WE dotycząca reklamy wprowadzającej w błąd i reklamy porównawczej (Dz. U. UE. L. z 2006 r. Nr 376) oraz 2005/29/WE dotycząca nieuczciwych praktyk handlowych stosowanych przez przedsiębiorstwa wobec konsumentów na rynku wewnętrznym (Dz. U. UE. L. z 2005 r. Nr 149). To właśnie suplement diety i jego reklama budzi największe wątpliwości, których zazwyczaj nie ma w przypadku oceny produktów leczniczych ze względu na bardziej szczegółowe i restrykcyjne uregulowania prawne, zdecydowanie dłuższą obecność w obrocie oraz ugruntowane orzecznictwo. Istotny jest również zapis zawarty w art. 55 ust 2. pkt. 1 lit. d ustawy Pr. farm. mówiący, że reklama produktu leczniczego nie może sugerować, iż produkt ten jest produktem spożywczym.

\section{Reklama a etykietowanie}

W reklamie suplementów diety istotną rolę odgrywają również pojęcia takie jak etykietowanie, znakowanie oraz prezentacja. Regulacje dotyczące znakowania żywności, w tym suplementów diety, na poziomie krajowym zawarte są w rozporządzeniu Ministra Zdrowia z dnia 9 października 2007 r. w sprawie składu oraz oznakowania suplementów diety (Dz. U. Nr 196, poz. 1425) oraz w rozporządzeniu Ministra Rolnictwa i Rozwoju Wsi z dnia 23 grudnia 2014 r. w sprawie znakowania poszczególnych rodzajów środków spożywczych (Dz. U. z 2015 r. poz. 29). Choć informacje podane na etykietach służą najczęściej za informację handlowa, to w przypadku kwalifikacji produktów sensytywnych takich jak produkty lecznicze, a także suplementy diety, które w przyszłości być może również będą zaliczane do tej kategorii, informacje takie mogą zostać uznane za 
niedozwoloną reklamę. Uznanie takie może spowodować nałożenie kar na podmiot odpowiedzialny za dopuszczenie takiego produktu do obrotu, jak również zmianę podstawy prawnej na surowszą. Zazwyczaj dotyczy to produktów dopuszczonych do obrotu jako suplementy diety, kiedy to $\mathrm{w}$ związku $\mathrm{z}$ przekazywanymi treściami powinny być traktowane jako produkt leczniczy.

Dyrektywa 46/2002/WE w sprawie zbliżania ustawodawstw Państw Członkowskich odnoszących się do suplementów żywnościowych w art. 6 ust. 2 zawiera zapis, że „etykietowanie, prezentacja i reklama nie moga przypisywać suplementom żywnościowym właściwości zapobiegawczych, leczniczych lub uzdrawiających choroby ludzkie lub odnosić się do takich właściwości”. Reklama suplementów diety, biorąc pod uwagę szereg decyzji kompetentnych organów krajowych oraz orzecznictwo, bardzo często wprowadza w błąd poprzez przypisywanie, świadome lub nie, konkretnemu produktowi właściwości produktu leczniczego. Opierając się na zapisach dostępnych w obecnie obowiązującym stanie prawnym jasny wydaje się wniosek, że ocena reklamy suplementu diety jest utrudniona lub wręcz niemożliwa bez odwoływania się do ustawodawstwa dotyczącego produktów leczniczych.

Zgodnie z art. 2 pkt. 1 lit. j rozporządzenia Parlamentu Europejskiego i Rady nr 1169/2011/WE z dnia 25.10.2011 r. w sprawie przekazywania konsumentom informacji na temat żywności, za etykietowanie uznać można wszelkie napisy, dane szczegółowe, znaki handlowe, nazwy marek, ilustracje lub symbole odnoszące się do danego środka spożywczego i umieszczone na wszelkiego rodzaju opakowaniu, dokumencie, ulotce, etykiecie, opasce lub pierścieniu towarzyszącym takiej żywności lub odnoszącym się do niej. Oddzielną definicją została objęta „etykieta”, która oznacza metkę, znak firmowy lub handlowy, a także ilustrację oraz inny opis w formie pisanej, drukowanej, tłoczonej lub odbitej albo w inny sposób naniesiony na opakowanie lub pojemnik z żywnością. Może on być również załączony do opakowania lub pojemnika z żywnością (art. 2 pkt. 1 lit. i). Etykietowania nie należy mylić $\mathrm{z}$ reklamą, która dotyczy wyłącznie wypromowania konkretnego produktu celem jego sprzedaży. Etykiety zawierają wszelkie informacje o produkcie, które dotrą do konsumenta końcowego razem z tym produktem.

$\mathrm{Z}$ uwagi na to, że UE na swoim terytorium zapewnia wysoki poziom ochrony konsumenta, każdy produkt dopuszczony do obrotu na jej terytorium, zarówno wyprodukowany we wspólnocie, jak i ten importowany, musi być bezpieczny i odpowiednio etykietowany. W związku ze wzrostem zainteresowania konsumentów dotyczącym odżywiania, dostęp do szczegółowych, rzetelnych i pełnych informacji o produktach znajdujących się na rynku jest szczególnie ważny i oczekiwany. W rozporządzeniu 1969/2011/WE wskazano o konieczności zapewnienia konsumentom odpowiedniego informowania na temat spożywanej przez nich żywności. Dostęp taki jest gwarancją zachowania wysokiego poziomu ochrony zdrowia konsumentów. W tym celu państwa członkowskie UE wyznaczyły bardzo wysokie standardy ochrony dotyczące praw konsumenta $\mathrm{w}$ relacjach z przedsiębiorcą, a także między samymi przedsiębiorcami.

W preambule rozporządzenia 178/2002/WE (Dz. U. UE. L. z 2002 r. Nr 31) jasno wskazano, że naczelną zasadą ogólnego prawa żywnościowego (OPŻ) jest zapewnienie konsumentowi podstawy do dokonywania świadomych wyborów dotyczących spożywanej przez niego żywności i uniemożliwienie praktyk mogących wprowadzić go w błąd. Parlament Europejski i Komisja Europejska dążą do wypracowania kompleksowych definicji traktujących szeroko o prawie dotyczącym informacji na temat żywności, również w formach innych niż przekazywanie informacji za pomocą etykiety, tak by pole do 
swobodnej interpretacji było jak najbardziej zawężone, a problemów natury prawnej w związku z klasyfikacją powyższych produktów było jak najmniej.

W rozporządzeniu 1969/2011/WE zawarto również szczegółowe dane dotyczące prezentacji, jednak jej nie zdefiniowano. Dlatego też prezentację należy interpretować zgodnie z przepisami dyrektywy $\mathrm{nr}$ 46/2002/WE w sprawie zbliżania ustawodawstw państw UE odnoszących się do suplementów żywnościowych oraz powyższego rozporządzenia. Pojęcie prezentowania utożsamiane jest najczęściej z opakowaniem suplementu diety. Dotyczy jego kształtu, materiału lub materiałów z jakich został wykonany, znajdującego się wokół niego otoczenia w miejscu sprzedaży np. aptece, oraz z jego eksponowaniem. Prezentacja wiążę się również z właściwym suplementem diety, czyli jego formą np. w postaci tabletki czy innych dróg podania, charakterystycznych dla produktów leczniczych.

\section{Reklama wprowadzająca konsumenta w błąd}

Zgodnie z art. 16 ust. 1 pkt. 2 ustawy o zwalczaniu nieuczciwej konkurencji taką reklamą jest ta wprowadzająca konsumenta w błąd i mogąca przez to wpływać na podejmowane przez niego decyzje $\mathrm{w}$ sprawie nabywania określonych towarów i usług. Definicję reklamy zawarto w dyrektywie 2006/114/WE. Wskazuje ona, iż reklama to „przedstawienie w jakiejkolwiek formie w ramach działalności handlowej, gospodarczej, rzemieślniczej lub wykonywania wolnych zawodów w celu wspierania zbytu towarów lub usług, w tym nieruchomości, praw i zobowiązań" (art. 2 lit. a).

Definicja powyższa jest bardzo szeroka, bowiem nie obejmuje wyłącznie produktów, ale również usługi, prawa oraz zobowiązania. Zgodnie z postanowieniami powyższego artykułu, reklamą wprowadzającą w błąd jest taka, która przez obraną formę powoduje wprowadzenie $\mathrm{w}$ błąd osoby lub osób, do których jest skierowana. Zwodnicza natura reklamy może wpłynąć na wybory konsumentów, czyli wpływać na postępowanie gospodarcze przez co jasnym jest, że szkodzi konkurentowi (art. 2 pkt. b). Zachowanie takie godzi więc $w$ kluczowe wartości UE, takie jak konkurencyjny rynek wewnętrzny i swobody. W dyrektywie tej szczegółowo uregulowano zasady prowadzenia reklamy porównawczej, czyli odwołującej się wprost do działań podmiotów konkurencyjnych, zarówno w zakresie towarów, jak i usług (art. 2 pkt. c).

Do stwierdzenia, czy reklama wprowadza odbiorcę w błąd, konieczne jest dokładne przeanalizowanie wszystkich towarzyszących jej okoliczności podanych w przekazie danych. Pojęcie reklamy wprowadzającej w błąd to nie tylko podawanie nieprawdziwych danych, ale również informacji niejasnych, przedstawianych w sposób mogący być różnie interpretowany przez odbiorcę. Charakter taki mogą mieć słowa lub wyrażenia niejednoznaczne, gdzie jedno $\mathrm{z}$ tych znaczeń jest niezgodne z prawdą. Taką reklamą jest również, celowe lub nie, wywołanie mylnego wrażenia u odbiorcy, a także pominięcie albo przemilczenie faktów. Biorąc pod uwagę czy konkretna reklama wprowadza konsumenta w błąd, konieczne jest odniesienie się do wypracowanego modelu przeciętnego konsumenta, czyli takiego, który jest osobą nieuważną, nie ma pełnej wiedzy o konkretnej tematyce oraz jest podatny na sugestie zawarte w reklamie. Wpływ takiej reklamy musi być istotny i odbijać się na podejmowanych przez konsumenta decyzjach gospodarczych.

Dyrektywa 2010/13/WE (Dz. U. UE. L. z 2010 r. Nr 95) definiując reklamę telewizyjną wskazuje, że ta oznacza wszelkiego rodzaju ogłoszenia związane $\mathrm{z}$ 
działalnością handlową, gospodarczą, rzemieślniczą lub działalnością w ramach wolnego zawodu rozpowszechniane przez przedsiębiorstwo publiczne lub prywatne lub osobę fizyczną w zamian za opłatę lub podobne wynagrodzenie lub rozpowszechniane przez to przedsiębiorstwo lub tę osobę fizyczną w celach autopromocji, w celu promocji odpłatnego dostarczania towarów lub świadczenia usług, w tym nieruchomości, praw i zobowiązań.

Wprowadzające konsumentów w błąd jest również wykorzystywanie w reklamach suplementów diety fikcyjnych specjalistów z zakresu zdrowia, takich jak lekarze lub farmaceuci. Katalog takich specjalistów nie został przez ustawodawcę sprecyzowany. Traktuje o tym art. 12 rozporządzenia 1924/2006, mówiący o zakazie odwoływania się w oświadczeniach zdrowotnych do zaleceń poszczególnych specjalistów (art. 12 pkt c). Mogą oni jednak reklamować taki produkt, ale tylko wtedy, gdy nie odwołują się do oświadczeń zdrowotnych. Niedopuszczalne jest również sugerowanie, iż niespożycie danej żywności mogłoby mieć wpływ na zdrowie (art. 12 pkt a), a także szybkość i wielkość obniżenia masy ciała (art. 12 pkt b).

Do takich wniosków doszedł Sąd Ochrony Konkurencji i Konsumentów w wyroku z dnia 14 sierpnia 2013 r. stwierdzając, że „błąd polegający na wskazaniu, że osoba występująca w reklamie ma tytuł naukowy profesora i jest dietetykiem może mieć wpływ na decyzję konsumenta co do zakupu reklamowanego produktu" (Wyrok Sądu..., 2013). Kluczowe w powyższym orzeczeniu jest stwierdzenie, iż profesjonalista, jakim jawi się odbiorcy reklamy profesor, może wpłynać na jego decyzję o zakupie konkretnego produktu. Co ważne, produktem tym był suplement diety, a nie produkt leczniczy. Pojawienie się w spocie reklamowym lekarza polecającego ten produkt, przeciętnemu konsumentowi mogłoby kojarzyć się z właściwościami produktu leczniczego i tym samym wprowadzić go w błąd (Wyrok Sądu..., 2013).

Reklama suplementu diety nie może wskazywać na właściwości produktu, które powinny być przypisywane produktowi leczniczemu. W wyroku WSA w Warszawie z dnia 15 października 2013 r. (Wyrok Wojewódzkiego..., 2013). Sąd stwierdził, że zamieszczenie w reklamie rozpowszechnianej w Internecie, czyli trafiającej do wielu osób w różnym wieku oraz mogących nie posiadać istotnej wiedzy na temat przedstawianych produktów, informacji „wskazania do stosowania - choroba lokomocyjna”, która to znajduje się na liście Międzynarodowej Klasyfikacji Chorób i Problemów Zdrowotnych, wprowadza konsumenta w błąd co do właściwości tego produktu oraz przypisuje temu suplementowi diety właściwości zapobiegania chorobom lub ich leczenia, które powinny charakteryzować produkt leczniczy.

$\mathrm{W}$ powyższej sprawie opierano się na art. 46 pkt. b ustawy o bezpieczeństwie żywności i żywienia, mówiącym o zakazie odwoływania się do oświadczeń zdrowotnych przypisujących środkowi spożywczemu działania lub właściwości, których nie posiada. Powyższy artykuł został uchylony w wyniku nowelizacji w 2015 r. Przedmiotowe postępowanie rozpoczęło się jeszcze przed nowelizacją dlatego wyrok uwzględnił poprzedni stan prawny i do tych zapisów odwoływał się Sąd. Mimo zmiany ustawy i uchylenia powyższego artykułu, tezy wywiedzione w tym postępowaniu, jak i w innych orzeczeniach opierających się na tym artykule przez Sądy pozostają aktualne.

Zgodnie z przepisami Państwowy Inspektor Sanitarny stwierdził, że zamieszczenie w reklamie powyższego wskazania, może spowodować u konsumenta mylne wrażenie, iż jest to produkt leczniczy zapobiegający objawom ww. jednostki chorobowej. Zgodnie $\mathrm{z}$ dalszą argumentacją organu, zażywanie suplementu diety, a nie leku, może doprowadzić do problemów ze zdrowiem. W tym przypadku wskazano, że jego zażywanie mogło 
doprowadzić do wycieńczenia organizmu. Reklama została przeprowadzona w Internecie, a więc jej zasięg można uznać za znaczny.

Podmioty profesjonalne, działające na rynkach spożywczym oraz farmaceutycznym, powinny przywiązywać szczególną uwagę do prawidłowego stosowania przepisów prawa żywnościowego, zwłaszcza jeśli chodzi o wymagania w zakresie oznakowania i prezentacji środków spożywczych. Obecne ustawodawstwo nie wyklucza jednoczesnej reklamy produktu leczniczego i suplementu diety pod warunkiem ścisłego interpretowania i przestrzegania obowiązujących przepisów. Należy również pamiętać, że oznakowanie wprowadzające w błąd to nie tylko oznakowanie nieprawdziwe czy mylące, ale również niepełne, niewystarczająco precyzyjne czy wieloznaczne.

W artykule 27 pkt. 6 u.b.ż.ż wskazane jest, że reklama, a także prezentacja i znakowanie suplementów diety, nie mogą zawierać informacji stwierdzających lub sugerujących, iż wystarczające dla organizmu ilości składników odżywczych nie mogą być dostarczone wraz ze zbilansowaną i zróżnicowaną dietą. Zapis ten pokazuje wagę roli racjonalnego ustawodawcy $\mathrm{w}$ ówczesnym prawie. Chce on zapobiec niepotrzebnemu i często nieracjonalnemu spożywaniu suplementów diety, a także ograniczyć wpływ reklamodawcy kierującego się wyłącznie zyskiem i sterującego popytem.

Ustawa powyższa dostatecznie klarownie określa, na podstawie artykułu 27 pkt 3, wymagania dla producenta suplementu diety wskazując, iż produkt taki trafiając do konsumenta finalnego powinien zawierać opakowanie. Cały powyższy artykuł zawiera wiele ograniczeń dla reklamy suplementów diety, na podstawie których można ustalić jakie informacje muszą obligatoryjne znaleźć się na opakowaniu, a także jakie z nich są dozwolone, a jakie zakazane.

U.b.ż.ż. jeszcze przed nowelizacją zawierała zapis traktujący o konieczności oznaczania produktu jako „suplement diety”, samodzielnie lub tuż obok nazwy handlowej preparatu. W obecnym stanie prawnym wymóg takiego zapisu znajduje się jedynie w rozporządzeniu w sprawie składu oraz znakowania suplementów diety. W rozporządzeniu tym, jak również w dyrektywie 2002/46/WE, gdzie zapisano, iż „nazwa”, pod jaką sprzedaje się produkty objęte niniejszą dyrektywą, brzmi "suplementy żywnościowe", nie doprecyzowano $\mathrm{w}$ jaki sposób zamieszczać taką treść. Dla reklamodawcy szczególnie ważne były wymogi dotyczące wielkości, napisu, konkretnego umiejscowienia $\mathrm{w}$ przypadku występowania nazwy handlowej, rodzaju i wielkości czcionki, ilości występowania takiego oznaczenia, by nie narażać się na kary ze strony organów kontrolnych.

Rynek suplementów diety jest obszarem, na którym niezwykle trudno jest stworzyć produkt, którego jeszcze na rynku nie ma. Większość z nich zawiera te same substancje czynne dostępne $\mathrm{W}$ różnych formach, produkowane przez wielu producentów. Wprowadzając konkretny suplement diety na rynek należy być niezwykle ostrożnym, aby nazwą, kształtem i kolorystyką opakowania nie naruszyć zasad uczciwej konkurencji. Problemy z zakresu reklamy suplementów diety nie dotyczącą więc tylko ochrony konsumenta przed przedsiębiorca, ale też interesów samych przedsiębiorców na konkretnym rynku.

Tezę taką postawił Sąd Najwyższy w wyroku z dnia 22 stycznia 2010 r. wskazując, że „Swoistość segmentu rynku na którym sprzedawane są preparaty magnezowe, a która sprowadza się do tego, że ten sam albo bardzo podobny towar uzyskuje przewage u odbiorców, dzięki swoistej nazwie oraz reklamie produktu i jego opakowaniu, wymaga tym większej ostrożności przy wprowadzaniu nowego produktu, aby poprzez 
wprowadzenie do obrotu bardzo podobnie opakowanego i nazwanego towaru, nie wprowadzić konsumentów w błąd i nie odebrać ich w ten sposób innemu producentowi" (Wyrok Sądu..., 2010).

Ustana o zwalczaniu nieuczciwej konkurencji w art. 10 ust. 1 traktującym o wprowadzających w błąd oznaczeniach towarów i usług jasno wskazuje, co jest czynem nieuczciwej konkurencji. W wyroku z dnia 19.09.2008 r. Sąd Okręgowy zakazał pozwanym niedozwolonych działań tj. wprowadzania do obrotu preparatu magnezowego „M” w szczegółowo określonym w tym wyroku opakowaniu, a także wycofanie ich z obrotu i zniszczenie oraz umieszczenie przeproszeń w ogólnopolskich dziennikach. Sąd Apelacyjny w stosunku do naruszenia art. 10 § 2 ustawy o zwalczaniu nieuczciwej konkurencji podzielił zdanie Sądu Okręgowego wskazując, że „o istotnym podobieństwie obu spornych produktów świadczy również zbieżność wielu elementów szaty graficznej ich opakowań, takich jak: określenie połączenia pierwiastka magnezu z witaminą w określonej konfiguracji, pisane łącznie, podobną czcionką utrzymane w podobnej kolorystyce oraz posługujące się zbliżonymi do siebie elementami kuli” (Wyrok Sądu..., 2010).

Sąd Najwyższy wskazał, że Sądy I i II instancji trafnie orzekły o naruszeniu art. 10 ustawy o zwalczaniu nieuczciwej konkurencji argumentując, że ,jest bezsporne, że oznaczenia magnezu "MG" oraz witaminy "B6" są oznaczeniami, zawierającymi ogólnodostępne informacje, które weszły do języka potocznego. Połączenie tych nazw w odpowiedniej kolejności prowadzi jednak do stworzenia nowego oznaczenia, które zawiera już nie tylko ogólnodostępne informacje, ale służy oznaczeniu jednego z występujących na rynku preparatów magnezowych" (Wyrok Sądu..., 2010). W tym przypadku producent nie zachował szczególnej ostrożności, wymaganej zwłaszcza w obrocie profesjonalnym. Zarówno nazwa, jak i opakowanie tego suplementu diety wykazywało znaczne podobieństwo w porównaniu do preparatu już dostępnego na rynku. Wydaje się, że wpływ na tak wydane orzeczenie miało również to, że reklama suplementu diety Powoda prowadzona była w szczególności w radiu. Nazwy obu suplementów diety w formie audio brzmiały niemal identycznie, dlatego zachodziło duże prawdopodobieństwo wprowadzenia przeciętnego konsumenta w błąd. Zachowanie Pozwanego godziło więc w transparentność rynku przez wprowadzenie w błąd co do produkowanego przez niego towaru.

Obecnie obowiązujące akty prawne regulujące reklamę suplementów diety i produktów leczniczych, nie zabraniają wprost łącznej reklamy tych produktów. Możliwość wspólnej reklamy takich towarów jest istotna zwłaszcza dla podmiotów, które zajmują się produkcją oraz wprowadzaniem do obrotu zarówno suplementów diety, jak i produktów leczniczych. Jest to zagadnienie szczególnie ważne w przypadku, gdy pewna substancja czynna, w zależności od jej dawki, może być suplementem diety oraz produktem leczniczym. Przy reklamie takiej kluczowy jest zapis art. 3a Pr. farm. mówiący o tym, że jeżeli produkt jednocześnie spełnia kryteria produktu leczniczego i suplementu diety, pierwszeństwo mają zapisy ustawy Prawo farmaceutyczne. Ważne jest wyeksponowanie różnic pomiędzy produktami, tak by konsument nie został wprowadzony w błąd. Z przekazu reklamowego musi w sposób klarowny i jednoznaczny wynikać różna klasyfikacja produktów. Jeżeli treść reklamy spełni takie warunki, nie zostanie zakwestionowana przez kompetentne organy (Kondrat (red.), 2012).

Główny Inspektor Farmaceutyczny w decyzji z dnia 21 grudnia 2007 r. nakazal natychmiastowe zaprzestanie prowadzenia niezgodnej $\mathrm{z}$ przepisami reklamy produktu leczniczego podanej do publicznej wiadomości (Sławatyniec, Mazurek, 2011; 
Decyzja..., 2007). Reklama została opublikowana w cotygodniowym dodatku do „Gazety Wyborczej” - „Wysokie Obcasy”. Zawarto w nim łączną reklamę dwóch produktów suplementu diety i produktu leczniczego. Głównym hasłem treści przekazanej w reklamie było wyrażenie „Wybierz swoją drogę podania”. Zgłaszający naruszenie art. 46 u.b.ż.ż. oraz art. 55 ust. 2 pkt 1 lit. a, b, d ustawy prawo farmaceutyczne stwierdził, że łączne prezentowanie tych produktów pod takim hasłem sugeruje, że jedyna różnica pomiędzy prezentowanymi preparatami to droga podania. Przy czym zauważyć należy, iż „droga podania" to wyrażenie charakterystyczne dla produktów leczniczych.

Generalny Inspektor Farmaceutyczny wszczą na tej podstawie postępowanie i jednocześnie wystapił do strony o wyjaśnienia. Pełnomocnik wskazał, że główne hasło reklamy nie może być rozpatrywane $\mathrm{w}$ oderwaniu od pozostałej treści, która w sposób jasny dla przeciętnego konsumenta i wyczerpujący wyjaśnia skład i właściwości produktu leczniczego „L.” oraz suplementu diety „p”. W treści zawarto również zalecenie konsultacji z lekarzem lub farmaceuta, niezbędne przy reklamie produktów leczniczych. Zdaniem pełnomocnika reklama zawiera informacje, że na rynku dostępne są dwa odmienne produkty - lek i suplement diety i w żadnym ze swych elementów nie zawiera treści zakazanych przez art. 55 ust. 2 pkt 1 lit. a, b, d. W treści przedmiotowej reklamy nie zawarto informacji o możliwości uniknięcia porady lekarskiej czy zabiegu chirurgicznego. Nie wskazano też, że osoba zdrowa przyjmująca produkt leczniczy poprawi swój stan zdrowia lub jest to produkt leczniczy.

Organ, na podstawie ustawy Pr. farm., powoływał się na to, że wskazanie w reklamie suplementu diety na możliwość skonsultowania się z lekarzem lub farmaceutą kwalifikuje go jako lek, a co tym idzie suplement diety podlega jej przepisom. Wprowadzające w błąd jest również hasło reklamy mówiące o drodze podania, gdyż konsument może zrozumieć, iż tylko droga podania odróżnia te dwa produkty.

\section{Naruszenie zbiorowych interesów konsumenta}

Reklama suplementów diety może być uznana za praktykę naruszającą zbiorowe interesy konsumentów. Ustawa nie definiuje jednak pojęcia ,zbiorowe interesy konsumenta”. W doktrynie uważa się jednak, że „mamy do czynienia z takim interesem, gdy działania przedsiębiorcy dotyczą zbiorowości i mogą dotknąć każdego potencjalnego klienta tego przedsiębiorcy, czyli gdy są powszechne" (Decyzja..., 2008). Decyzję w tej sprawie wydał Prezes UOKiK. Za praktykę naruszającą zbiorowe interesy konsumentów, na podstawie art. 27 ust. $1 \mathrm{w}$ związku z art. 24 ust. 1 i ust. 2 pkt 3 ustawy z dnia 16 lutego 2007 r. o ochronie konkurencji i konsumentów, uznano reklamę na stronie sklepu internetowego, gdzie podano informację o działaniach leczniczych pewnego suplementu diety. Działanie takie stanowi również naruszenie art. 16 ust. 1 pkt 1 UZNK. Organ wskazywał, że przedmiotowemu produktowi, klasyfikowanemu jako suplement diety, nie można przypisywać właściwości produktu leczniczego. Podmiot, który zmieścił reklamę o takiej treści na swojej witrynie, działa jako profesjonalista, więc ciąży na nim szczególna odpowiedzialność w zakresie dostarczania konsumentom rzetelnych i pełnych informacji. W treści reklamy zawarto określenia polegające na działaniu wspomagającym i łagodzącym: w stanach zapalnych jamy ustnej i gardła, w męczącym kaszlu, w stanach obniżonej odporności organizmu. Stany takie określa się w medycynie jako stany chorobowe (Decyzja..., 2008). Przypisywanie takich właściwości suplementowi diety 
wprowadza konsumenta w błąd. Istotne jest również to, iż przestrzeganie obowiązujących przepisów dotyczących reklamy suplementów diety i produktów leczniczych nie dotyczy tylko podmiotu wprowadzającego je na rynek, ale także innych specjalistów zajmujących się ich obrotem hurtowym czy właśnie farmaceutów, będących specjalistami. Takie zdanie wyraził w przedmiotowej decyzji Prezes UOKiK stwierdzając, że „profesjonalista musi być kompetentny tzn. reprezentować odpowiedni poziom wiedzy fachowej, aby mógł udzielać informacji, a udzielając jej musi zachować się odpowiednio starannie, tak aby poziom informacji udzielonej odpowiadał tej wiedzy, odniesionej do konkretnej sytuacji" (Decyzja..., 2008).

\section{Główny Inspektor Sanitarny (GIS) i jego rola}

Organem odpowiedzialnym za kontrolę wprowadzenia do obrotu suplementów diety jest Główny Inspektor Sanitarny (GIS). Podmiot działający na rynku spożywczym, wprowadzający suplement diety na rynek po raz pierwszy, zobowiązany jest do powiadomienia o tym GIS. Traktuje o tym art. 29 ust. 4 u.b.ż.ż. Powiadomienia takiego dokonuje się poprzez formularz elektroniczny dostępny na stronie organu. Szczegółowość informacji zawartych $\mathrm{w}$ powiadomieniu uregulowana jest $\mathrm{w}$ art 29. ust. u.b.ż.ż. Jeżeli suplement diety znajduje się w obrocie na rynku innego państwa członkowskiego UE, należy wskazać właściwy organ tego państwa, który zgodnie z procedurami tego państwa, został powiadomiony o wprowadzeniu tego środka do obrotu lub wydał odpowiednie zezwolenie.

$\mathrm{Na}$ podstawie art. 30 u.b.ż.ż. GIS może zdecydować się na przeprowadzenie postępowania mającego na celu wyjaśnienie, czy wskazany w powiadomieniu suplement diety, analizując zawarty w dokumentach skład, właściwości poszczególnych składników i przeznaczenie, może być kwalifikowany jako środek spożywczy zgodnie z przedstawioną przez podmiot informacją oraz czy spełnia wymagania konieczne dla danego rodzaju środka spożywczego. W przypadku suplementu diety sprawdza się czy zawiera witaminy i składniki mineralne oraz inne substancje wskazane w rozporządzeniu Ministra Zdrowia w sprawie składu oraz oznakowania suplementów diety oraz stosowanemu wprost rozporządzeniu 1925/2006 Parlamentu Europejskiego i Rady w sprawie dodawania do żywności witamin i składników mineralnych oraz niektórych innych substancji (Dz. U. UE. L. z 2006 r. Nr 404, str. 26-38). Główny Inspektor Sanitarny sprawdza również, czy wskazany $\mathrm{w}$ powiadomieniu suplement diety nie spełnia wymagań innego produktu stosowanego przez ludzi, zwłaszcza produktu leczniczego, uregulowanego $\mathrm{w}$ prawie farmaceutycznym (art. 20 pkt 2).

GIS może żądać opinii Zespołu do Spraw Suplementów Diety, który działa w Ramach Rady Sanitarno-Epidemiologicznej, powołanej na podstawie art. 9 ustawy o Państwowej Inspekcji Sanitarnej (art. 31 u.b.ż.ż). Inspektor Sanitarny może zobowiązać podmiot rejestrujący do przedłożenia opinii jednostki naukowej stwierdzającej, że przedmiotowy środek spełnia wymagania wskazane $\mathrm{w}$ art. 30 ust. 1 u.b.ż.ż. Kiedy zachodzą przesłanki o spełnieniu warunków przypisywanych produktowi leczniczemu, organ może zobowiązać podmiot wprowadzający konkretny suplement diety do przedłożenia opinii Urzędu Rejestracji Produktów Leczniczych, Wyrobów Medycznych i Produktów Biobójczych. 


\section{Podsumowanie}

Z uwagi na to, że suplementy diety, uznane przez ustawodawcę za żywność, odbierane są przez konsumenta jako produkty bezpieczne i nie mające większego wpływu na zdrowie, konieczne jest podawanie na ich temat pełnych, jednoznacznych informacji oraz prezentowanie właściwych oznaczeń. Mimo, że ograniczanie pewnych metod reklamy lub całkowitego ich zakazu jest ingerencją w wolność gospodarczą zagwarantowaną w Konstytucji RP oraz swobodę działalności gospodarczej zagwarantowaną w traktatach Unii Europejskiej, uzasadnione jest to ochroną życia i zdrowia człowieka. Jednakże konieczne jest uwzględnienie zasady proporcjonalności. Reklama suplementów diety, o których traktuje ustawa o bezpieczeństwie żywności i żywienia, w swej treści zawiera jedynie odesłania do innych aktów prawnych. Brakuje w niej również definicji reklamy przedmiotowych produktów.

Granica przy kwalifikacji, czy dany produkt jest suplementem diety lub produktem leczniczym nie jest sztywna, a nieocenione w tych przypadkach stają się orzecznictwo i dorobek doktryny. Brak w tym zakresie odpowiednich i wyczerpujących badań i analiz oraz wykazu odpowiednich norm traktujących o maksymalnych zawartościach konkretnych substancji, stwarza problem z kwalifikacją produktów z pogranicza. Dlatego też legislator wybrał drogę najprostszą, kwalifikując powyższe jako produkty lecznicze na podstawie ustawy Pr. farm. Obecnie obowiązujące regulacje prawne, dotyczące reklamy suplementów diety, nie odpowiadają na realne problemy i potrzeby konsumentów oraz przedsiębiorców.

Kompleksowe uregulowanie rynku suplementów diety jest w stanie wyjaśnić niejasne i sporne dotąd kwestie, a co najważniejsze $\mathrm{z}$ perspektywy ochrony zdrowia i życia konsumenta, doprecyzowanie regulacji dotyczących suplementów diety wykluczy działania przedsiębiorców dążące do kwalifikowania ich produktów na podstawie bardziej liberalnych przepisów. Szczególnie widoczna jest zróżnicowana szczegółowość regulacji dotyczących suplementów diety i produktów leczniczych.

Obecnie obowiązujące akty prawne, zwłaszcza niedookreślone zapisy regulujące reklamę suplementów diety, nie dają możliwości jasnego rozróżnienia produktów leczniczych i suplementów diety. Pierwsze, uznane za środki spożywcze, nie muszą spełniać restrykcyjnych wymogów, takich jak zawarte w ustawie Prawo farmaceutyczne. Ustawa ta zawiera szczegółowe przepisy dotyczące reklamy w rozdziale IV. Co więcej, zapis art. 3a wskazuje, iż $\mathrm{w}$ razie spełniania przez dany produkt kryteriów produktu leczniczego, wchodzi on w zakres takiego reżimu prawnego. Bez watpienia, jest to zapis podwyższający zakres ochrony i bezpieczeństwa konsumenta. Jednak zadaniem dobrej legislacji jest stworzenie kompleksowych i jasnych przepisów prawnych. W tym przypadku ustawodawca nie uregulował dostatecznie kwestii stwarzającej problemy praktyczne, a jedynie rozszerzył krąg produktów traktowanych jako produkty lecznicze. W związku z tym, produkty sprawiające problemy w klasyfikacji tj. produkty z pogranicza, najczęściej zaczynają podlegać reżimowi prawa farmaceutycznego. 


\section{Literatura}

Decyzja z dnia 21.12.2007 nr GIF-P-R-450-98-5-JD/07 (Decision 21.12.2007 of Main Pharmaceutical Inspector). Decyzja z dnia 30.09.2008 r. nr RŁO 46/2008. Prezesa Urzędu Ochrony Konkurencji i Konsumenta, delegatura w Lodzi (Decision of President of the Office of Competition and Consumer Protection).

Dyrektywa 2002/46/WE Parlamentu Europejskiego i Rady z dnia 10 czerwca 2002 r. w sprawie zbliżenia ustawodawstw Państw Członkowskich odnoszących się do suplementów żywnościowych (Directive 2002/46/EC of the European Parliament and of the Council of 10 June 2002 on the approximation of the laws of the Member States relating to food supplements) (Dz. U. UE. L. z 2002 r. Nr 183, z późn. zm.).

Dyrektywa 2005/29/WE Parlamentu Europejskiego i Rady z dnia 11 maja 2005 r. dotycząca nieuczciwych praktyk handlowych stosowanych przez przedsiębiorstwa wobec konsumentów na rynku wewnetrznym (Directive 2005/29/EC of the European Parliament and of the Council of 11 May 2005 concerning unfair business-toconsumer commercial practices in the internal market and amending Council Directive 84/450/EEC, Directives 97/7/EC, 98/27/EC and 2002/65/EC of the European Parliament and of the Council and Regulation (EC) No 2006/2004 of the European Parliament and of the Council ('Unfair Commercial Practices Directive')) (Dz. U. UE. L. z 2005 r. Nr 149).

Dyrektywa 2006/114/WE Parlamentu Europejskiego i Rady z dnia 12 grudnia 2006 r. dotycząca reklamy wprowadzającej w błąd i reklamy porównawczej (wersja ujednolicona) (Directive 2006/114/EC of the European Parliament and of the Council of 12 December 2006 concerning misleading and comparative advertising (codified version)) (Dz. U. UE. L. z 2006 r. Nr 376).

Dyrektywa Parlamentu Europejskiego i Rady 2010/13/UE z dnia 10 marca 2010 r. w sprawie koordynacji niektórych przepisów ustawowych, wykonawczych i administracyjnych państw członkowskich dotyczących świadczenia audiowizualnych usług medialnych (dyrektywa o audiowizualnych usługach medialnych) (wersja ujednolicona) (Directive 2010/13/EU of the European Parliament and of the Council of 10 March 2010 on the coordination of certain provisions laid down by law, regulation or administrative action in Member States concerning the provision of audiovisual media services (Audiovisual Media Services Directive)) (Dz. U. UE. L. z 2010 r. Nr 95, z późn. zm.).

Grochowska, M. (2007). Bezpieczeństwo żywności i żywienia: komentarz do ustawy oraz przepisów wspólnotowych (Food and Nutrition Safety: the Commentary to Polish Act and European Provisions), Gdańsk, Ośrodek Doradztwa i Doskonalenia Kadr.

Harasimiuk, D.E. (2011). Zakazy reklamy towarów w prawie europejskim i polskim (Prohibitions on Advertising of Goods in European and Polish Law). Warszawa, Oficyna Wolters Kluwer Business.

Kępiński, M. (2001). Rynek farmaceutyczny a prawo własności intelektualnej (Pharmaceutical Market and Intellectual Property Law). Warszawa, Wydawnictwo C. H. Beck.

Kondrat M. (red.) (2012). Prawo suplementów diety (Food Suplement Law). Warszawa, Wolters Kluwer Polska.

Kondrat, M. (2016). Prawo farmaceutyczne. Komentarz (Pharmaceutical Law. The Commentary). Wyd. II. Warszawa, Wolters Kluwer Polska.

Korzycka, M., Wojciechowski, P. (2017). System prawa żywnościowego (The Food Law System). Warszawa, Wolters Kluwer Polska.

Korzycka-Iwanow, M. (2007). Prawo żywnościowe. Zarys prawa polskiego i wspólnotowego (Food law. The Outline of Polish and European Law). Warszawa, Wydawnictwo Prawnicze Lexis Nexis.

Namysłowska, M. (2012). Reklama. Aspekty prawne (Advertisement. Legal Aspects), Warszawa, Wolters Kluwer Polska.

Olszewski W.L. (red.) (2016). Prawo farmaceutyczne. Komentarz (Pharmaceutical Law. The Commentary). Warszawa, Wolters Kluwer Polska.

Ożóg, M. (2009). System handlu produktem leczniczym i produktami pokrewnymi. Problematyka prawna (Trading System for the Medicinal Product and Related Products. Legal Issues). Warszawa, Wydawnictwo Prawnicze LexisNexis.

Rozporzadzenie (WE) nr 178/2002 Parlamentu Europejskiego i Rady z dnia 28 stycznia 2002 r. ustanawiające ogólne zasady i wymagania prawa żywnościowego, powołujące Europejski Urząd ds. Bezpieczeństwa Żywności oraz ustanawiające procedury w zakresie bezpieczeństwa żywności (Regulation (EC) No 178/2002 of the European Parliament and of the Council of 28 January 2002 laying down the general principles and requirements of food law, establishing the European Food Safety Authority and laying down procedures in matters of food safety) (Dz. U. UE. L. z 2002 r. Nr 31, str. 1 z późn. zm.).

Rozporządzenie (WE) nr 1924/2006 Parlamentu Europejskiego i Rady z dnia 20 grudnia 2006 r. w sprawie oświadczeń żywieniowych i zdrowotnych dotyczacych żywności (Regulation (EC) No 1924/2006 of the European Parliament and of the Council of 20 December 2006 on nutrition and health claims made on foods) (Dz. U. UE. L. z 2006 r. Nr 404, str. 9-25 z późn. zm.). 


\section{K. Ksiażczak, B. Nieścior}

Rozporządzenie (WE) nr 1925/2006 Parlamentu Europejskiego i Rady z dnia 20 grudnia 2006 r. w sprawie dodawania do żywności witamin i składników mineralnych oraz niektórych innych substancji (Regulation (EC) No 1925/2006 of the European Parliament and of the Council of 20 December 2006 on the addition of vitamins and minerals and of certain other substances to foods) (Dz. U. UE. L. z 2006 r. Nr 404, str. 26-38 z późn. zm.).

Rozporządzenie Ministra Rolnictwa i Rozwoju Wsi z dnia 23 grudnia 2014 r. w sprawie znakowania poszczególnych rodzajów środków spożywczych (Regulation of the Ministry of Agriculture of 23 December 2014 on the labelling of several food stuffs) (Dz. U. z 2015 r. poz. 29 z późn. zm.).

Rozporządzenie Ministra Zdrowia z dnia 9 października 2007 r. w sprawie składu oraz oznakowania suplementów diety (Regulation of the Ministry of Health of 9 October 2007 on the composition and labelling of food supplements) (Dz. U. z 2015 r. poz. 2032).

Skubisz, R., Sagan, R. (1998). Prawo reklamy. Zbiór przepisów. Orzecznictwo. Literatura (Advertising law. Collection of Provisions. Jurisprudence. Literature). Lublin, Wydawnictwo MORPOL.

Sławatyniec, Ł., Mazurek, K. (2011). Reklama produktów leczniczych. Przegląd orzecznictwa Głównego Inspektora Farmaceutycznego (2004-2010) (Advertising of medicinal products. Review of the jurisprudence of the Main Pharmaceutical Inspector). Warszawa, Wolters Kluwer.

Ustawa z dnia 16 kwietnia 1993 r. o zwalczaniu nieuczciwej konkurencji (Act of 16 April 1993 On combating unfair competition) (Dz. U. z 2003 r. Nr 153, poz. 1503 z późn. zm.).

Ustawa z dnia 16 lutego 2007 r. o ochronie konkurencji i konsumentów (Act of 16 February 2007 on competition and consumer protection) (Dz. U. z 2017 r. poz. 229).

Ustawa z dnia 23 sierpnia 2007 r. o przeciwdziałaniu nieuczciwym praktykom rynkowym (Act of 23 August 2007 on combating unfair commercial practices) (Dz. U. z 2016 r. poz. 3 z późn. zm.)

Ustawa z dnia 25 sierpnia 2006 r. o bezpieczeństwie żywności i żywienia (Act of 25 August 2006 on Food and Nutrition Safety) (Dz. U. z 2017 r. poz. 149 z późn. zm.).

Ustawa z dnia 6 września 2001 r. Prawo farmaceutyczne (Act of 6 September 2001 Pharmaceutical Law) (Dz. U. z 2016 r. poz. 2142 z późn. zm.)

Wyrok Sądu Najwyższego z dnia 22 stycznia 2010 r. (Judgment of the Supreme Court of 22 January 2019) V CSK 192/09.

Wyrok Sądu Ochrony Konkurencji i Konsumentów z dnia 14 sierpnia 2013 r. (Judgment of the Court of Competition and Consumer Protection of 14 August 2013) XVII AmA 124/11.

Wyrok Wojewódzkiego Sądu Administracyjnego w Warszawie z dnia 15 października 2013 r. (Judgment of the Regional Administrative Court in Warsaw of 15 October 2013) VII SA/Wa 1136/13.

Do cytowania / For citation:

Książczak K., Nieścior B. (2018). Reklama suplementów diety - analiza prawna. Problemy Rolnictwa Światowego, 18(1), 130-142; DOI: 10.22630/PRS.2018.18.1.12

Książczak K., Nieścior B. (2018). Advertisement of Diet Supplement - Legal Analysis (in Polish). Problems of World Agriculture, 18(1), 130-142; DOI: 10.22630/PRS.2018.18.1.12 